\title{
Don't believe everything you read especially in medicine and wine (fake news)
}

\author{
Shaun McCann ${ }^{1}$
}

Received: 3 August 2018 / Accepted: 3 August 2018

c) Springer Nature Limited 2018

'It's either a forgery or a damn fine original'.

Frank Sullivan, 1892-1976. American Humourist.

Nobody believes everything they read. That statement may be truer now than in previous years. However, looking more closely at published 'scientific' data' and claims in the commercial field we need to be more circumspect. Scientific research, even if reviewed by the most respected Academics, may, in fact be fraudulent. The reliability of 'hard data' was recently demolished by the editor of The Lancet, Dr. Richard Horton, who declared that $50 \%$ of published 'data' was impossible to verify [1]. Arguably the most infamous example of medical forgery was the publication by Hwang Woo-suk in Science in 2004/5. He and his team had to retract claims published in Science about embryonic stem cell research. The claims had been carefully peerreviewed but nevertheless the research was later proven to be fraudulent and subsequently withdrawn.

We all know about frauds in art (Han van Meegeren being one of the most well known) but frauds in wine making/selling also exist. The billionaire wine collector William Koch was probably very annoyed when he discovered that the wine he thought was from Thomas Jefferson's collection was not (Jefferson apparently kept meticulous records and went to great lengths to verify the provenance of fine wines he purchased). Koch was awarded $\$ 12$ million by the District Court in Manhattan when he

Shaun McCann

shaunrmccann@gmail.com

1 University of Dublin Trinity College, Haematology Emeritus, Dublin, Dublin, Ireland successfully sued Eric Greenberg, the wine dealer from whom he had purchased the beverage.

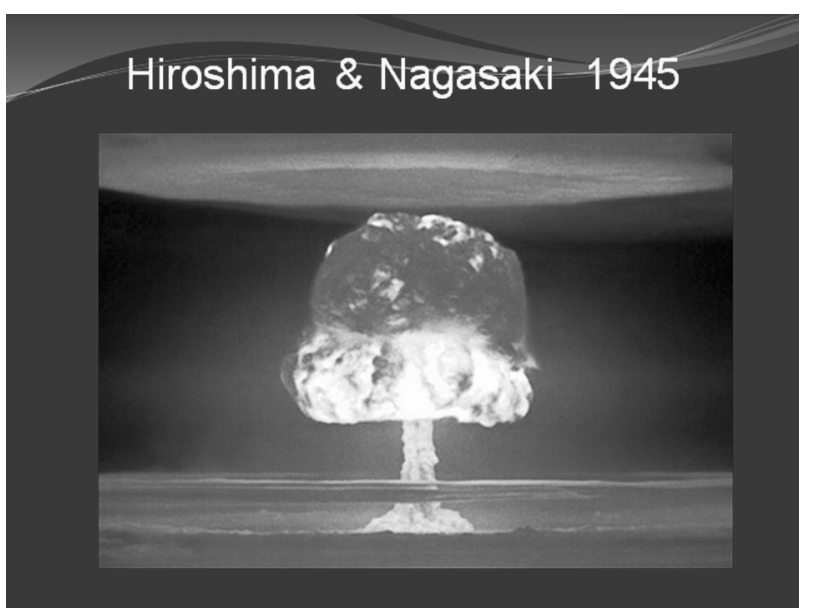

Fig. 1. The atomic bomb explosion. ${ }^{137} \mathrm{Cs}$ is an anthropomorphic (man-made) isotope which did not exist until June 16, 1945 when the 'atomic bomb' was exploded at the trinity site in New Mexico. Consequently a bottle of wine dated before or after this time by testing for ${ }^{137} \mathrm{Cs}$

Another well-known case of wine fraud involving Koch was when he sued Rudy Kurniawan who had put a quantity of grand cru Clos Saint-Denise and Laurent Ponsot 1945 on the market. However the wines in question had not been bottled until 1982, so thereby hangs a tail!

What about new technology and detection of wine fraud? In Australia, carbon-14 isotopes in grapes can be detected in wine made during nuclear testing in the 1950s-1960s. This provides a time-clock to ascertain the date of wine production of wine from before or after this period.

More recently, as reported in The New York Times, a group of French scientists have been using radiobiological techniques to verify wine dates without opening the bottle! To quote Phillipe Hubert PH and his team: 'For many years the neutrino group in the CENBG has been involved in the 
development of low background $\gamma$-ray spectrometers, based on the use of HPGe crystals. When applied to radioactivity measurements of wine in bottles, it has been shown that besides the well-known isotope ${ }^{40} \mathrm{~K}$, the wine also contains trace amounts of ${ }^{137} \mathrm{Cs}$ (less than $1 \mathrm{~Bq} / \mathrm{l}$ ) with an activity depending on the vintage. This technique has thus led to the possibility to date the wine bottles of vintages between 1952 and 1980 and to verify the year written on the label or on the cork. Since the measurements do not require opening the bottle, the technique has also proved to be very useful for detecting counterfeit wines of the 19th century and first half of the 20th century'.

Mihir Zaveri writing in July 2018 says that French scientists have found traces of the isotope Cesium -137, which is a man-made isotope and does not occur in nature, in Californian wine, which they associate with the Fukushima disaster. Wines containing traces of Cesium-137 could not have existed before the mid-20th century. According to Michael Pravikoff, a scientist working with the team, there is no risk to health, a view expressed by the California Department of Public Health and the WHO, so it must be correct!

In the meantime I'll keep drinking wine and not worry too much about radiation and health risks!

\section{Compliance with ethical standards}

Conflict of interest The author declares that he has no conflict of interest.

\section{References}

1. Horton R. What is medicine's 5 sigma? 2015. www.thelancet.com. 385. 